\title{
PLA/PGA and its co-Polymers in Alveolar Bone Regeneration. A Systematic Review
}

\author{
PLA/PGA y sus Copolímeros en Regeneración Ósea Alveolar. Una Revisión Sistemática
}

Marcelo Parra',2; María Paz Moya ${ }^{2,3}$; Carolina Rebolledo';

Ziyad S. Haidar ${ }^{4,5}$; Juan Pablo Alister ${ }^{1,2}$ \& Sergio Olate ${ }^{1,2}$

\begin{abstract}
PARRA, M.; MOYA, M. P.; REBOLLEDO, C.; HAIDAR, Z. S.; ALISTER, J. P. \& OLATE, S. PLA/PGA and its co-polymers in alveolar bone regeneration. A systematic review. Int. J. Odontostomatol., 13(3): 258-265, 2019.

ABSTRACT: The aim of this research was to perform a systematic review to identify the most frequent uses of PLA/ PGA in alveolar bone regeneration and their results. A study was designed to answer the question: What are the most frequent uses of PLA/PLGA and their copolymers in alveolar bone regeneration?. A systematic search was done on MEDLINE, EMBASE and LILACS from April 1993 to December 2017. The search string used on MEDLINE was: (((polylactic acid) OR PLA) OR PLA-based copolymers) OR PLA blends) OR PLA scaffolds)) AND ((("Bone Regeneration"[Mesh]) OR bone regeneration) $O R$ guided bone regeneration). The search was complemented by a manual review of the references from the articles included. Most of the studies selected were weak and, regarding the most frequent uses of PLA/PGA, 13 studies used it as a resorbable membrane, two as an absorbable mesh, one as an absorbable screw and three as filling material. Based on our results, the authors consider that PLA/PGA requires a delicate relation between the mechanical resistance and the degradation process. PLA/PGA does not interrupt bone regeneration; however, the influence in cellular events related to bone regeneration and later osseointegration have not been identified.
\end{abstract}

KEY WORDS: poly lactic acid poly ethylene glycol, bone substitute, bone grafting

\section{INTRODUCTION}

Bone regeneration is a process that depends on several factors (Sheikh et al., 2017). This process becomes more complex when bone grafts are needed to allow bone regeneration related to adequate volume and shape, necessary for orofacial rehabilitation (Sheikh et al., 2015).

Biodegradable polymers have been designed to be used alone or in combination with bone substitute in some reconstructive process (Nygaard-Østby et al., 2008), where polylactic acid (PLA) and polyglycolic acid (PLG) are well known materials. PLA is a biodegradable polymer obtained from lactic acid, which has osteoconductive properties and has been used in various presentations. Although its applications were originally mainly in orthopedics (Athanasiou et al.,
1998), for a long time it has been used in the craniofacial area for bone regeneration, as filling material in post-extraction alveolar preservation (Madan et al., 2014), as resorbable membrane in the treatment of periodontal bone lesions and guided bone regeneration (Kini et al., 2016; Rowe et al., 2016), as resorbable internal fixation to secure bone block grafts (Mazzonetto et al., 2010), as resorbable sutures (He et al., 2014) and as a carrier for growth factors and bone morphogenetic proteins (BMPs) (Ma et al., 2016), among others.

Nevertheless, there is limited evidence to indicate the applications and influences of PLA in craniofacial bone regeneration or the success rates of treatments performed on human beings. The aim of this study is

\footnotetext{
${ }^{1}$ Department of Oral, Facial and Maxillofacial Surgery, Hospital A. G. P., Lautaro, Chile.

${ }^{2}$ Center of Excellence in Morphological and Surgical Studies - CEMyQ, Universidad de La Frontera, Temuco, Chile.

${ }^{3}$ Faculty of Health Science, Universidad Autónoma de Chile, Temuco, Chile.

${ }^{4}$ BioMAT'X Research Group, Faculty of Dentistry, Universidad de Los Andes, Santiago, Chile

${ }^{5}$ Program in BioMedicine, CIIB-PMI Faculty of Medicine, Universidad de los Andes, Santiago, Chile.
} 
to conduct a systematic review of the literature to identify the application of PLA and its copolymers in alveolar bone regeneration.

\section{MATERIAL AND METHOD}

Protocol and eligibility criteria. A systematic literature review was carried out to respond to the research question: What are the most frequent uses of PLA/ PLGA and its copolymers in maxillofacial bone regeneration? The inclusion criteria for the articles were: 1) primary studies, 2) published in English, Spanish, Portuguese or French, 3) performed on humans, and 4) evaluated the use of PLA in bone regeneration. Secondary studies, studies performed on animals and those that used PLA or its copolymers for purposes other than bone regeneration were excluded. The report was prepared according to the Preferred Reporting Items for Systematic Reviews and Meta-Analyses (PRISMA) (Moher et al., 2009).

Sources of information and search strategy. A systematic search was done on MEDLINE, EMBASE and LILACS from April 1993 to December 2017. The search string used on MEDLINE was: $((()($ polylactic acid) OR PLA) OR PLA-based copolymers) OR PLA blends) OR PLA scaffolds)) AND ((("Bone Regeneration"[Mesh]) OR bone regeneration) OR guided bone regeneration). The search was complemented by a manual review of the references from the articles included.

Study selection and data extraction. The title and abstract of the studies identified in the search were selected independently by 2 calibrated reviewers (MP and M.P.M.). In case of differences between the reviewers, consensus was reached by discussion or in consultation with a third reviewer (SO). The reviewers were not blinded to the authors or journals.

Data were collected independently by two authors (M.P., M.P.M.) using a predefined and standardized data extraction form. A pilot test was used to homogenize criteria between reviewers. Any discrepancy was resolved by discussion or in consultation with a third reviewer (SO). Gray literature was not reviewed systematically.

Risk of bias in the individual studies. To assess the risk of bias in the studies, the Effective Public Health Practice Project's Quality Assessment Tool (Effective
Public Health Practice Project, 1998) was used, which contains six domains: selection bias, study design, confounders, blinding, data collection methods, and withdrawals and dropouts. The overall grading for each study was identified as strong when no component was weak, moderate when only one component was weak, and weak when two or more components were described as weak.

\section{RESULTS}

Study selection. The combined search identified 565 references. After excluding 60 duplicates, a review of the titles excluded 400 studies, 105 articles passed to abstract review, 27 articles were evaluated in full text, and 10 potentially relevant articles were excluded after reading the full text. After a manual review of the articles, 19 were ultimately included (Fig. 1).

Characteristics of the studies. Table I details the characteristics of the studies included. 2 articles were retrospective (Mau et al., 2012; Rosen \& Rosen, 2013)

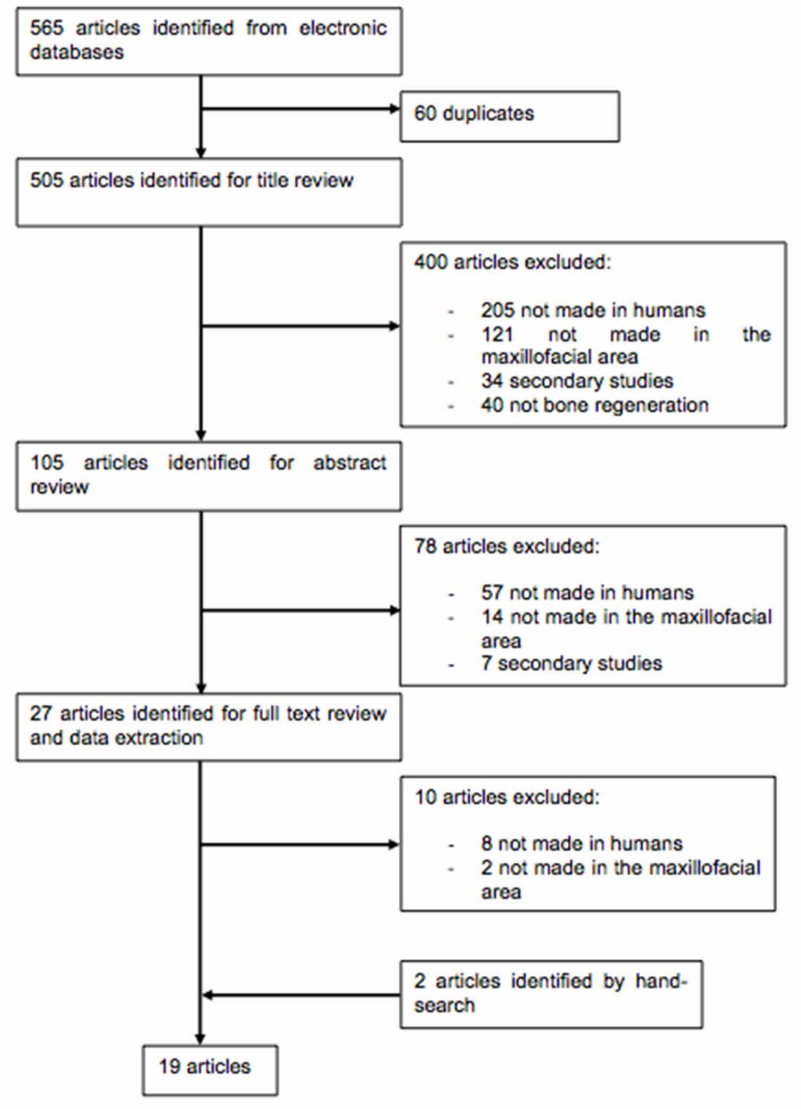

Fig. 1. Flowchart of systematic review. 
Table I. Description of the articles included in this systematic review.

\begin{tabular}{|c|c|c|c|c|c|c|c|}
\hline Author/year & Type of study & $\mathrm{N}^{\circ}$ patients & Male & Female & $\begin{array}{c}\text { Age (years) } \\
\text { average/range }\end{array}$ & Evaluation method & $\begin{array}{l}\text { Follow-up } \\
\text { time }\end{array}$ \\
\hline Simion et al., 1996 & Prospective & 5 & N/R & N/R & $44-69$ & Histological & 6 months \\
\hline Simion et al., 1997 & Prospective & 9 & N/R & N/R & $30-64$ & Clinical & 8 months \\
\hline Vernino et al., 1998 & Prospective & 40 & 19 & 21 & $32-71$ & Retroalveolar x-ray & 12 months \\
\hline Trejo et al., 2000 & Prospective & 30 & 11 & 19 & $30-55$ & $\begin{array}{l}\text { Clinical and } \\
\text { retroalveolar } x \text {-rays }\end{array}$ & 12 months \\
\hline Rosen \& Reynolds, 2001 & Prospective & 9 & 7 & 2 & $32-81$ & $\begin{array}{l}\text { Clinical and } \\
\text { histological }\end{array}$ & 5.7 months \\
\hline Stoller et al., 2001 & Prospective & 1 & 0 & 1 & 42 & $\begin{array}{l}\text { Clinical and } \\
\text { histological }\end{array}$ & 25 months \\
\hline Serino et al., 2003 & Prospective & 45 & 14 & 31 & $35-64$ & $\begin{array}{l}\text { Clinical and } \\
\text { histological }\end{array}$ & 6 months \\
\hline $\begin{array}{l}\text { Nygaard-Østby et al., } \\
2008\end{array}$ & Prospective & 40 & 20 & 20 & $42-67$ & Clinical and x-ray & 9 months \\
\hline Serino et al., 2008 & Prospective & 20 & 8 & 12 & $32-64$ & $\begin{array}{l}\text { Clinical and } \\
\text { histological }\end{array}$ & 3 months \\
\hline Lyons et al., 2008 & Prospective & 29 & 18 & 11 & $43-67$ & Clinical & 9 months \\
\hline Nickles et al., 2009 & Prospective & 16 & 8 & 8 & $29-61$ & Clinical & 120 months \\
\hline Pretzl et al., 2009 & Prospective & 15 & 3 & 12 & $22-64$ & Clinical and x-ray & 120 months \\
\hline Matsuo et al., 2010 & Prospective & 2 & 1 & 1 & 29 and 66 & Clinical and $\mathrm{CBCT}$ & 28 and 33 \\
\hline Mazzonetto et al., 2010 & Prospective & 10 & 2 & 8 & $28-60$ & $\begin{array}{c}\text { Clinical, panoramic } \\
\text { x-ray and CBCT }\end{array}$ & 6 months \\
\hline Mau et al., 2012 & Retrospective & 1 & N/R & N/R & 42 & $\begin{array}{l}\mathrm{CBCT} \text { and } \\
\text { retroalve olar } \mathrm{x} \text {-ray }\end{array}$ & 1 year \\
\hline Baenna et al., 2013 & Prospective & 8 & N/R & N/R & N/R & СВСТ & 11 months \\
\hline Rosen \& Rosen, 2013 & Retrospective & 43 & 22 & 21 & $25-75$ & Clinical & 23 weeks \\
\hline Schneider et al., 2014 & Prospective & 40 & N/R & N/R & $18-70$ & $\begin{array}{l}\text { Clinical, x-ray and } \\
\text { histological }\end{array}$ & 6 months \\
\hline Yagihara et al., 2013 & Prospective & 62 & 41 & 21 & $12-78$ & X-rays & $\begin{array}{c}88.2 \\
\text { months }\end{array}$ \\
\hline
\end{tabular}

and 17 were prospective (Simion et al., 1997; Vernino et al., 1998; Trejo et al., 2000; Rosen \& Reynolds, 2001; Stoller et al., 2001; Serino et al., 2003, 2008; Lyons et al., 2008; Nygaard-Østby et al.; Nickles et al., 2009; Pretzl et al., 2009; Matsuo et al., 2010; Mazzonetto et al.; Rodriguez y Baena et al., 2013; Schneider et al., 2014; Yagihara et al., 2013). The average sample size among the studies was 26 subjects, ranging between 5 and 62 subjects. In terms of the results evaluation method, one study conducted a histological analysis (Simion et al., 1996), 2 studies an x-ray analysis (Vermino et al.; Yagihara et al.), 4 studies a clinical analysis (Simion et al., 1997; Lyons et al.; Nickles et al.; Rodriguez y Baena et al.), 3 studies clinical and $\mathrm{x}-$ ray analyses (Nygaard-Østby et al.; Trejo et al.; Pretzl et al.), 4 studies clinical and histological analyses (Stoller et al.; Serino et al., 2003, 2008), one study a clinical analysis and with cone beam computed tomography (CBCT) (Matsuo et al.), one study clinical, $x$-ray analyses and CBCT (Mazzonetto et al.), one study an x-ray analysis and CBCT (Mau et al.), one study an analysis with CBCT (Rodriguez y Baena et al.) and one study clinical, x-ray and histological analyses Schneider et al.).

Related to the most frequent uses of PLA and its copolymers, 13 studies used it as resorbable membrane (Nygaard-Østby et al.; Mau et al.; Simion et al., 1996, 1997; Vermino et al.; Trejo et al.; Stoller et al.; Lyons et al.; Nickles et al.; Pretzl et al.; Schneider et al.), two as absorbable mesh (Matsuo et al.; Yagihara et al.), one as absorbable screws (Mazzonetto et al.) and three as filling material (Serino et al., 2003, 2008; Rodriguez y Baena et al.) (Table II).

Risk of bias in the studies. The evaluation of the risk of bias in the studies included is reported in Figure 2. In selection bias, the first domain to be assessed, all the articles were classified as weak because they included non-probability or convenience sampling, which does not provide adequate representativity of the participants. This can cause an imbalance in some characteristics relevant to the participants like age, gender or health status, which can each influence the 
PARRA, M.; MOYA, M. P.; REBOLLEDO, C.; HAIDAR, Z. S.; ALISTER, J. P. \& OLATE, S. PLA/PGA and its co-polymers in alveolar bone regeneration. A systematic review. Int. J. Odontostomatol., 13(3): 258-265, 2019.

Table II. Use and outcome for the use of PLA/PGA

\begin{tabular}{cl}
\hline Author/year & \multicolumn{1}{c}{ Use of PLA } \\
\hline Simion et al., 1996 & $\begin{array}{l}\text { Resorbable membrane in GBR, comparing it with a PLA membrane presented greater bone formation than in } \\
\text { non-resorbable polytetrafluorethylene membrane (e- the control group, but less than in the e-PTFE group. } \\
\text { PTFE) and a control non-membrane group. }\end{array}$
\end{tabular}

Simion et al., 1997 Resorbable PLA/PGA membrane associated with $88.56 \%$ closing of the fenestration in the PLA/PGA group autogenous graft in GBR to cover the bone was obtained, with no significant differences with the efenestrations resulting from the installation of dental PTFE group. implants, comparing it to e-PTFE membrane.

Vernino et al., Resorbable membrane in the treatment of class II No significant differences related to the amount of bone 1998 furcation defect.

Trejo et al., 2000 Absorbable membrane (PLA/PGA) used No significant differences between use of PLA membrane independently or in association with DFDBA in the alone or associated with DFDBA treatment of periodontal defects.

Rosen \& Absorbable membrane plus DFDBA in the treatment 10 of 11 defects achieved complete coverage of the bone Reynolds, 2001 of fenestrations and dehiscence after dental implant defect. The histological evaluations revealed formation of installation viable bone.

Stoller et al., 2001 Absorbable membrane in treatment dass II furcation New bone formation was observed at the site of interest. defect.

Serino et al., 2003 "Fisiograft" (PLA/PGA) sponge, used as filling After 6 months, the bone resorption was lower in the material in post-extraction alveolar preservation, experimental group at all the sites studied compared to the comparing it with no-graft healing through clot control group. Histological analysis revealed mineralized, formation. mature and well-structured bone tissue.

Nygaard-Østby et Absorbable membrane plus autogenous graft, The use of a PLA membrane does not afford additional al., 2008 compared to bo ne graft in the treatment of value in the treatment of periodontal bone defects with periodontal bone defects autogenous bone graft.

Serino et al., 2008 Fisiograft sponge, used as filling material in post After $3 \mathrm{~m}$ onths, the histological analyses showed highly extraction alveolar preservation, comparing it with mineralized and well-structured cancellous bone formation, natural healing through clot formation observing a greater amount of bone in the apical portion than the cervical portion, and no particles of filling material were found in any of the samples.

Lyons et al., 2008 Absorbable membrane associated with DBFA, with or There was formation of new bone; however, there were no without $4 \%$ doxycydine in treatment of class II significant differences between using or not using $4 \%$ furcation defects in lower molars doxycycline associated with the membrane

Nickles et al., 2009

Absorbable membrane in GTR, used in periodontal defects, comparing it to OFP (open flap debridement) therapy

Pretzl et al., 2009 Absorbable membrane in GTR compared to an

They report that in both therapies there was an increase in bone tissue height, but that their analysis failed to determine statistical differences between the two groups.

Matsuo et al., absorbable membrane of another material. insertion but did establish differences between the groups.

The authors report improvements in the levels of vertical

Absorbable PLLA/HA mesh associated with The authors conclude that the PLLA/HA mesh adapts autogenous graft used in mandibular reconstructions optimally to the mandible and the post-operative CBCT showed good bone quality. $\begin{array}{ll}\text { Mazzonetto et al., } & \text { Absorbable screw for the fixation of autogenous bone } \\ 2010 & \text { grafts for the subsequent installation of dental }\end{array}$ implants.

49 absorbable PLLA screws were placed, of which 4 were implants.

lost. The authors of the work conclude that the absorbable
PLLA screws do not interfere with bone healing or with the osseointegration of dental implants.

Mau et al., 2012 Absorbable membrane

The authors report an ad verse biological reaction resulting from the use of an absorbable PLA membrane.

Baenna et al., 2013

Filling material in maxillary sinus in combination with hydroxyapatite, comparing it to DBB

The average increase in height of newly formed bone was

Rosen \& Rosen, 2013

As an absorbable membrane in post-extraction They presented only 4 adverse results, mainly poor bone alveolar preservation, for the later installation of healing in the labial area. However, in no case did it render dental implants, used alone or together with graft the installation of implants impossible. material

Schneider et al., Absorbable membrane in GBR after the installation of They found no statistically significant differences between 2014 dental implants, comparing it with an e-PTFE the two membranes membrane.

Yagihara et al., 2013

Resorbable mesh associated with autogenous bone Good acceptance and stability of the PLA mesh was PCBM (particulate cancellous bone and marrow) in observed and a low incidence of resorption of the bone graft. mandibular bone reconstructions.

results in their own way. In the study design, five studies were classified as strong and 14 as moderate. Although there were controlled clinical trials, most of the studies were prospective cohorts with no control group. With 


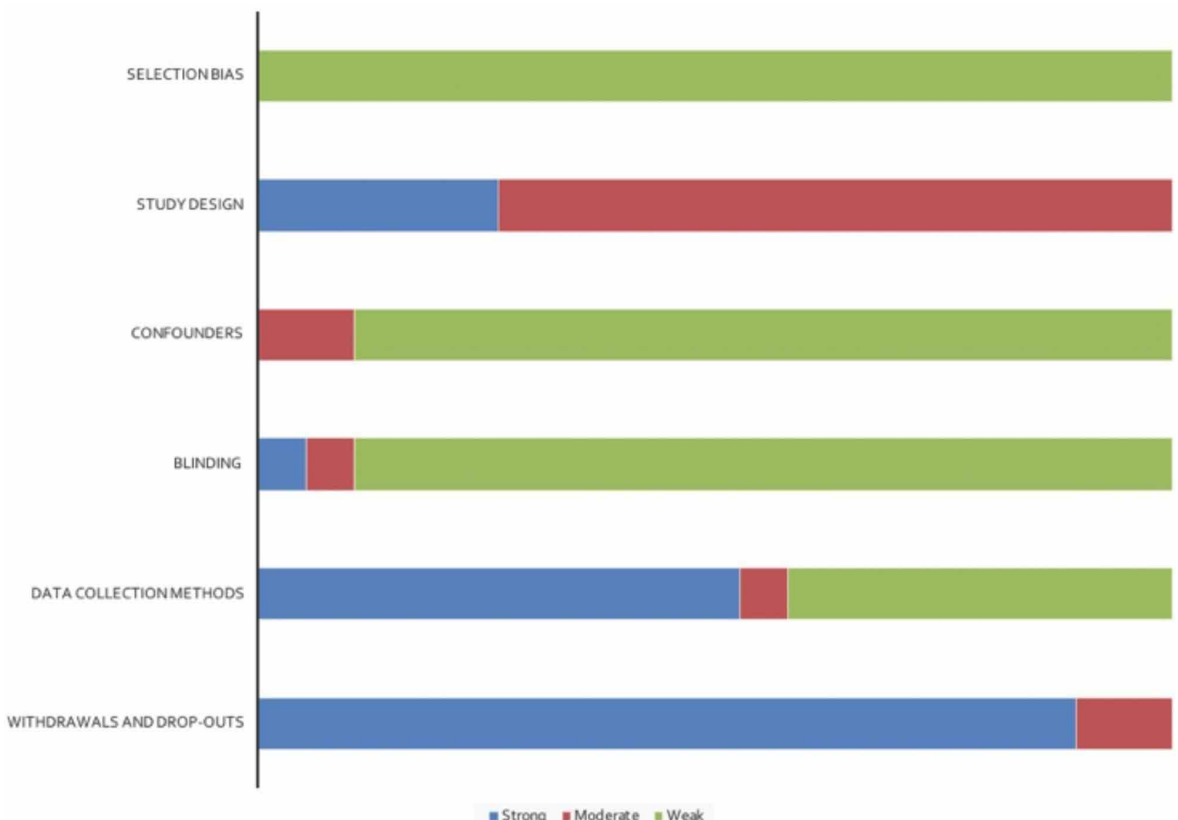

Fig. 2. Summary of risk of bias of the included studies

respect to confounder control, two were classified as moderate and 17 as weak. In terms of masking, one study was classified as strong because the patient and evaluator were blinded, one as moderate and the rest as weak. On the other hand, when analyzing the data collection methods, 10 were classified as strong, one as moderate and eight as weak, with the main strength being the use of validated methods, although not all showed high reliability. Finally, with respect to withdrawals and dropouts, this was the best evaluated domain because only in two studies were there subject dropouts; however, these did not exceed $20 \%$ of the sample. As far as the overall evaluation is concerned, 17 studies were catalogued as weak and two as moderate (Rodriguez y Baena et al.; Schneider et al.). All the studies had at least two domains rated as weak, so they were rated as weak due to the high risk of bias they present.

\section{DISCUSSION}

PLA/PGA and its copolymers are synthetic, resorbable and highly biocompatible materials (Athanasiou et al.) that have been used in different bone regeneration techniques; however, there is limited information to permit an analysis of the different forms of application and their potential impact on the bone regeneration process in the maxillae.
The variability of clinical presentations and the limitations of the studies do not permit a meta-analysis of results; a large number of the studies was weak in some categories, limiting their use as solid evidence in the best application of PLA/PGA.

According to our results, the most frequent use of these materials was as resorbable membrane in different procedures, mainly in the treatment of bone defects as a result of periodontitis and in bone augmentations related to dental implants surgery. The aim of this application was to allow the immobilization of the bone graft or bone substitute used, and to serve as a barrier to avoid the growth of connective tissue inside the bone substitute (Lee \& Kim, 2014).

For PLA / PGA related to implant dentistry, was performed the installation of dental implants in atrophic sites, and then installation of particulate xenograft covered by a PLGA membrane for stability of the filling and was compared to cases trated by non-absorbable ePTFE membrane (Scheneider et al.). After 6 months follow-up, survival rate of the dental implants in both groups was $100 \%$ and no differences was observed. This is consistent with other authors (Arunjaroensuk et al., 2018), who compared the use of a PLA / PGA membrane as an experimental group and a collagen membrane as a control in bone augmentation during dental implants istallation, also reporting a $100 \%$ survival of the implants in both groups.

Resorbable membrane with no resorption for 4 to 6 weeks, could be beneficial for bone regeneration, as was demonstrated in an experimental study on dogs (Lekholm et al., 1993); biodegradable implies the absence of secondary surgery for its removal. The few studies that reported the characteristics of these membranes indicated they were porous for attracting, trapping and retaining the fibroblasts and epithelial cells while maintaining the space for the growth of new bone and periodontal tissue (Barbeck et al., 2015).

Simion et al. (1996) conducted a study in humans and compared resorbable PLA/PGA 
membranes and non-resorbable polytetrafluorethylene (e-PTFE) membranes in the treatment of bone defects around implants installed immediately after extraction, without bone graft. After six months, they found significant differences in the amount of newly formed bone, being greater in the group where nonresorbable e-PTFE membrane was used. They indicated the rapid degradation time as the main cause of failure of the PLA/PGA membranes.

Simion et al. (1997), in a study of similar characteristics, found no statistically significant differences when using a resorbable or nonresorbable membrane after six months of follow-up. Similarly, using both types of membrane in the covering of periodontal bone defects associated with autogenous bone graft, other authors (Nygaard- $\varnothing$ stby et al.) found no significant differences in a comparison of the two membranes.

Another uses of PLA/PGA and its copolymers described in the maxillomandibular area was as filling in post-extraction alveolar preservation, a procedure performed to preserve or avoid large bone resorptions of the alveolar process after a tooth extraction, and thus achieve a subsequent successful installation of a dental implant (Scheyer et al., 2016). A great variety of materials has been used as filling in post-extraction alveoli with varying rates of success (locca et al., 2017). On the use of PLA/PGA in this therapy, Serino et al. (2003) created a PLA/PGLA sponge model that was applied in post-extraction alveoli. After six months of follow-up, it was noted that the loss of bone height was greater in the alveoli that were not treated with bone graft or filling than those treated with the application of the post-extraction sponge.

In another similar study, Serino et al. (2008) observed that in biopsies in the experimental group, there was intense osteoblastic activity and the presence of mature bone tissue for the most part, without observing residual particles of the PLA/PGLA filling; by contrast, a significant presence of connective tissue and immature bone tissue was observed in the control group. The authors reported that the degradation of PLA/PGA involves hydrolytic degradation (Cutright et al., 1974), whereas other materials like b-TCP are eliminated faster by remodeling-resorption than the PLA/PGA (evaluated six weeks after implantation) (Draenert et al., 2013); hence, the greater maintenance of the PLA could contribute to greater maintenance of the postextraction anatomy.
Another PLA-based application is the manufacture of osteosynthesis screws. Mazzonetto et al. reported the application of osteosynthesis screws for internal fixation of autogenous bone blocks extracted from the iliac crest, thereby avoiding the subsequent removal of the osteosynthesis for the installation of dental implants. The mechanical characteristics of these PLA/PGA screws have been evaluated for more than 15 years in the maxillofacial surgery literature, describing good results, similar to those obtained by titanium elements (Rodríguez-Chessa et al., 2014). In maxillofacial surgery, these osteosynthesis systems have been used in maxillofacial traumatology, orthognathic surgery and craniofacial surgery without presenting any changes in the bone repair mechanism of fractures or osteotomies (Ueki et al., 2012).

The complications associated with PLA/PGA screws are relatively low (Yang et al., 2013); a probable limitation in this reconstructive technique is that a screw guide is required prior to the installation of the screws, which can limit the use of compressive techniques between the bone graft and the native bone.

Based on our results, the authors estimate that the use of PLA/PGA requires a delicate relation between the mechanical resistance and the degradation process, so that the different presentations must contain differences in the composition of the products. A screw, for example, must be less flexible than a membrane or a sponge; thus, the elimination of the material must maintain a relationship with bone regeneration so that the new formation in a bone defect or in the osseointegration process is not interrupted. The results of this study show that the application of PLA does not interrupt bone regeneration; however, the influence of PLA on the physiological events of regeneration and osseointegration in the long term must be identified. New research studies with adequate methodology are necessaries for an evidence based decision.

PARRA, M.; MOYA, M. P.; REBOLLEDO, C.; HAIDAR, Z. S.; ALISTER, J. P. \& OLATE, S. PLA/PGA y sus co-polímeros en regeneración ósea alveolar. Una revisión sistemática. Int. J. Odontostomatol., 13(3): 268-265, 2019

RESUMEN:. El objetivo de esta revisión fue realizar una revisión sistemática de la literatura para identificar los usos más frecuentes de PLA/PGA en regeneración ósea en área maxilofacial y sus resultados. Se diseñó un estudio para responder a la pregunta: ¿Cuáles son los usos más frecuentes de PLA/PLGA y sus copolímeros en regeneración ósea 
en el sector maxilofacial?. Los estudios seleccionados fueron en su mayoría débiles y sobre los usos más frecuentes de PLA/PGA, 13 estudios lo utilizaron como membrana reabsorbible, 2 estudios como malla absorbible, un estudio como tornillo absorbible y 3 estudios como material de relleno. En base a nuestros resultados, los autores estiman que PLA/PGA requiere una delicada relación entre la resistencia mecánica que ofrece y la degradación que se produce; PLA/ PGA no interrumpe la regeneración ósea, sin embargo, no se ha identificado la potencialidad o influencia que presenta en los eventos celulares de la regeneración y posterior oseointegración.

PALABRAS CLAVE: PLA/PGA, sustituto óseo, injerto óseo.

\section{REFERENCES}

Arunjaroensuk, S.; Panmekiate, S. \& Pimkhaokham, A. The stability of augmented bone between two different membranes used for guided bone regeneration simultaneous with dental implant placement in the esthetic zone. Int. J. Oral Maxillofac. Implants, 33(1):206-16, 2018.

Athanasiou, K. A.; Agrawal, C. M.; Barber, F. A. \& Burkhart, S. S. SOrthopaedic applications for PLA-PGA biodegradable polymers. Arthroscopy, 14(7):726-37, 1998.

Barbeck, M.; Lorenz, J.; Kubesch, A.; Böhm, N.; Booms, P.; Choukroun, J.; Sader, R.; Kirkpatrick, C. J. \& Ghanaati, S. Porcine dermis-derived collagen membranes induce implantation bed vascularization via multinucleated giant cells: a physiological reaction? J. Oral Implantol., 41(6):e238-51, 2015.

Cutright, D. E.; Perez, B.; Beasley, J. D. 3rd; Larson, W. J. \& Posey, W. R. Degradation rates of polymers and copolymers of polylactic and polyglycolic acids. Oral Surg. Oral Med. Oral Pathol., 37(1):142-52, 1974

Draenert, M.; Draenert, A. \& Draenert, K. Osseointegration of hydroxyapatite and remodeling-resorption of tricalciumphosphate ceramics. Microsc. Res. Tech., 76(4):370-80, 2013.

Effective Public Health Practice Project. Quality Assessment Tool for Quantitative Studies. Hamilton (ON), Effective Public Health Practice Project, 1998. Available from: http://www.ephpp.ca/ index. html.

He, Y.; Hu, Z.; Ren, M.; Ding, C.; Chen, P.; Gu, Q. \& Wu, Q. Evaluation of PHBHHx and PHBV/PLA fibers used as medical sutures. J. Mater. Sci. Mater. Med., 25(2):561-71, 2014.

locca, O.; Farcomeni, A.; Pardiñas Lopez, S. \& Talib, H. S. Alveolar ridge preservation after tooth extraction: a Bayesian Network meta-analysis of grafting materials efficacy on prevention of bone height and width reduction. J. Clin. Periodontol., 44(1):104-14, 2017.

Kini, V.; Nayak, D. G. \& Uppoor, A. S. A clinical evaluation of biphasic calcium phosphate alloplast with and without a flowable bioabsorbable guided tissue regeneration barrier in the treatment of mandibular molar class II furcation defects. J. Contemp. Dent. Pract., 17(2):143-8, 2016.

Lee, S. W. \& Kim, S. G. Membranes for the guided bone regeneration. Maxillofac. Plast. Reconstr. Surg., 36(6):239-46, 2014.

Lekholm, U.; Becker, W.; Dahlin, C.; Becker, B.; Donath, K. \& Morrison, E. The role of early versus late removal of GTAM membranes on bone formation at oral implants placed into immediate extraction sockets. An experimental study in dogs.
Clin. Oral Implants Res., 4(3):121-9, 1993.

Lyons, L. C.; Weltman, R. L.; Moretti, A. J. \& Trejo, P. M. Regeneration of degree ii furcation defects with a $4 \%$ doxycycline hyclate bioabsorbable barrier. J. Periodontol., 79(1):72-9, 2008.

Ma, D.; An, G.; Liang, M.; Liu, Y.; Zhang, B. \& Wang, Y. A composited PEG-silk hydrogel combining with polymeric particles delivering rhBMP-2 for bone regeneration. Mater. Sci. Eng. C Mater. Biol. Appl., 65:221-31, 2016.

Madan, R.; Mohan, R.; Bains, V. K.; Gupta, V.; Singh, G. P. \& Madan, M. Analysis of socket preservation using polylactide and polyglycolide (PLA-PGA) sponge: a clinical, radiographic, and histologic study. Int. J. Periodontics Restorative Dent., 34(2):e3642, 2014.

Matsuo, A.; Chiba, H.; Takahashi, H.; Toyoda, J. \& Abukawa, H. Clinical application of a custom-made bioresorbable raw particulate hydroxyapatite/poly-L-lactide mesh tray for mandibular reconstruction. Odontology, 98(1):85-8, 2010.

Mau, L. P.; Cheng, C. W.; Hsieh, P. Y. \& Jones, A. A. Biological complication in guided bone regeneration with a polylactic acid membrane: a case report. Implant Dent., 21(3):171-4, 2012.

Mazzonetto, R.; Klüppel, L. E.; Neto, H. D.; Chessa, J. G. \& Nascimento, F. F. Reconstruction of severely resorbed maxilla with biodegradable polylactide screws: case series. Int. J. Oral Maxillofac. Implants, 25(4):821-5, 2010.

Moher, D.; Liberati, A.; Tetzlaff J, Altmant, D. G. \& PRISMA Group. Preferred reporting items for systematic reviews and metaanalyses: the PRISMA statement. PLoS Med., 6(7):e1000097, 2009.

Nickles, K.; Ratka-Krüger, P.; Neukranz, E.; Raetzke, P. \& Eickholz, $P$. Open flap debridement and guided tissue regeneration after 10 years in infrabony defects. J. Clin. Periodontol., 36(11):97683,2009

Nygaard-Østby, P.; Bakke, V.; Nesdal, O.; Nilssen, H. K.; Susin, C. \& Wikesjö, U. M. Periodontal healing following reconstructive surgery: effect of guided tissue regeneration using a bioresorbable barrier device when combined with autogenous bone grafting. A randomized controlled clinical trial. J. Clin. Periodontol., 35(1):37-43, 2008.

Pretzl, B.; Kim, T. S.; Steinbrenner, H.; Dörfer, C.; Himmer, K. \& Eickholz, P. Guided tissue regeneration with bioabsorbable barriers III 10-year results in infrabony defects. J. Clin. Periodontol., 36(4):349-56, 2009.

Rodriguez y Baena, R.; Lupi, S. M.; Pastorino, R.; Maiorana, C.; Lucchese, A. \& Rizzo, S. Radiographic evaluation of regenerated bone following poly(lactic-co-glycolic) acid/hydroxyapatite and deproteinized bovine bone graft in sinus lifting. J. Craniofac. Surg., 24(3):845-8, 2013.

Rodríguez-Chessa, J.; Olate, S.; Netto, H. D.; Noia, C.; de Moraes, M. \& Mazzonetto, R. In vitro resistance of titanium and resorbable (poly L-co-DL lactic acid) osteosynthesis in mandibular body fracture. Int. J. Oral Maxillofac. Surg., 43(3):362-6, 2014.

Rosen, P. S. \& Reynolds, M. A. Guided bone regeneration for dehiscence and fenestration defects on implants using an absorbable polymer barrier. J. Periodontol., 72(2):250-6, 2001.

Rosen, P. S. \& Rosen, A. D. Purposeful exposure of a polylactic acid barrier to achieve socket preservation for placement of dental implants: case series report. Compend. Contin. Educ. Dent., 34(1):34-8, 40, 2013.

Rowe, M. J.; Kamocki, K.; Pankajakshan, D.; Li, D.; Bruzzaniti, A.; Thomas, V.; Blanchard, S. B. \& Bottino, M. C. Dimensionally stable and bioactive membrane for guided bone regeneration: An in vitro study. J. Biomed. Mater. Res. B Appl. Biomater., 104(3):594-605, 2016.

Scheyer, E. T.; Heard, R.; Janakievski, J.; Mandelaris, G.; Nevins, M. L.; Pickering, S. R.; Richardson, C. R.; Pope, B.; Toback, G.; Velásquez, D. \& Nagursky, H. A randomized, controlled, 
PARRA, M.; MOYA, M. P.; REBOLLEDO, C.; HAIDAR, Z. S.; ALISTER, J. P. \& OLATE, S. PLA/PGA and its co-polymers in alveolar bone regeneration. A systematic review. Int. J. Odontostomatol., 13(3): 258-265, 2019.

multicentre clinical trial of post-extraction alveolar ridge preservation. J. Clin. Periodontol., 43(12):1188-99, 2016.

Schneider, D.; Weber, F. E.; Grunder, U.; Andreoni, C.; Burkhardt, R. \& Jung, R. E. A randomized controlled clinical multicenter trial comparing the clinical and histological performance of a new, modified polylactide-co-glycolide acid membrane to an expanded polytetrafluorethylene membrane in guided bone regeneration procedures. Clin. Oral Implants Res., 25(2):150-8, 2014.

Serino, G.; Biancu, S.; lezzi, G. \& Piattelli, A. Ridge preservation following tooth extraction using a polylactide and polyglycolide sponge as space filler: a clinical and histological study in humans. Clin. Oral Implants Res., 14(5):651-8, 2003.

Serino, G.; Rao, W.; lezzi, G. \& Piattelli, A. Polylactide and polyglycolide sponge used in human extraction sockets: bone formation following 3 months after its application. Clin. Oral Implants Res., 19(1):26-31, 2008.

Sheikh, Z.; Hamdan, N.; Ikeda, Y.; Grynpas, M.; Ganss, B. \& Glogauer, M. Natural graft tissues and synthetic biomaterials for periodontal and alveolar bone reconstructive applications: a review. Biomater. Res., 21:9, 2017.

Sheikh, Z.; Sima, C. \& Glogauer, M. Bone replacement materials and techniques used for achieving vertical alveolar bone augmentation. Materials, 8(6):2953-93, 2015.

Simion, M.; Misitano, U.; Gionso, L. \& Salvato, A. Treatment of dehiscences and fenestrations around dental implants using resorbable and nonresorbable membranes associated with bone autografts: a comparative clinical study. Int. J. Oral Maxillofac. Implants, 12(2):159-67, 1997.

Simion, M.; Scarano, A.; Gionso, L. \& Piattelli, A. Guided bone regeneration using resorbable and nonresorbable membranes: a comparative histologic study in humans. Int. J. Oral Maxillofac. Implants, 11(6):735-42, 1996.

Stoller, N. H.; Johnson, L. R. \& Garrett, S. Periodontal regeneration of a class II furcation defect utilizing a bioabsorbable barrier in a human. A case study with histology. J. Periodontol., 72(2):23842, 2001.

Trejo, P. M.; Weltman, R. \& Caffesse, R. Treatment of intraosseous defects with bioabsorbable barriers alone or in combination with decalcified freeze-dried bone allograft: a randomized clinical trial. J. Periodontol., 71(12):1852-61, 2000.

Ueki, K.; Okabe, K.; Moroi, A.; Marukawa, K.; Sotobori, M.; Ishihara, Y. \& Nakagawa, K. Maxillary stability after Le Fort I osteotomy using three different plate systems. Int. J. Oral Maxillofac. Surg., 41(8):942-8, 2012.

Vernino, A. R.; Ringeisen, T. A.; Wang, H. L.; Derhalli, M.; Rapley, J.; Nechamkin, S. J. \& Brekke, J. Use of biodegradable polylactic acid barrier materials in the treatment of grade II periodontal furcation defects in humans--Part I: A multicenter investigative clinical study. Int. J. Periodontics Restorative Dent., 18(6):57285, 1998.

Yagihara, K.; Okabe, S.; Ishii, J.; Amagasa, T.; Yamashiro, M.; Yamaguchi, S.; Yokoya, S.; Yamazaki, T. \& Kinoshita, Y. Mandibular reconstruction using a poly(L-lactide) mesh combined with autogenous particulate cancellous bone and marrow: a prospective clinical study. Int. J. Oral Maxillofac. Surg., 42(8):9629, 2013.

Yang, L.; Xu, M.; Jin, X.; Xu, J.; Lu, J.; Zhang, C.; Tian, T. \& Teng, L. Complications of absorbable fixation in maxillofacial surgery: a meta-analysis. PLoS One, 8(6):e67449, 2013.
Corresponding author:

Prof. Sergio Olate

Center of Excellence in Morphological and Surgical Studies

Universidad de La Frontera

Claro Solar 115

Temuco

CHILE

Email: sergio.olate@ufrontera.cl

Recibido : 15-03-2019

Aceptado: 22-05-2019 